\title{
GRM6 wt Allele
}

National Cancer Institute

\section{Source}

National Cancer Institute. GRM6 wt Allele. NCI Thesaurus. Code C51464.

Human GRM6 wild-type allele is located within and is approximately $30 \mathrm{~kb}$ in length. This allele, which encodes metabotropic glutamate receptor 6 protein, plays a role in glutamatergic neurotransmission and in the inhibition of the cyclic AMP cascade pathway. 